\title{
The Quaternary History of The Western Desert of Egypt as Recorded in The Abu EI-Egl Playa
}

\author{
Joakim Donner* \\ Mahmoud M. Ashour** \\ George A. Brook*** \\ Nabil S. Embabi**
}

\begin{abstract}
In the Abu El-Egl playa basin between Kharga and Dakhla, below the Abu Tartur plateau, over $10 \mathrm{~m}$ thick thinly stratified sediments remain as long dissected ridges. On the basis of luminescence ages they were deposited during the humid period in the Sahara corresponding to MIS 5, up to a level of a lake at about $180 \mathrm{~m}$ a.s.l. The floor, at about $170 \mathrm{~m}$ a.s.l., consisting of homogenous loamy material and sands with an early Holocene luminescence age, surrounds the ridges. The playa floor was later occupied at about 7000 yr BP according to radiocarbon ages of charcoal from fireplaces and a sample of ostrich eggshell. The main erosion of the old lake sediments was assumed to have taken place during the humid period of MIS 3, before the subsequent arid period of MIS 2. This is supported by the finds of Middle Palaeolithic artefacts on the playa floor between the ridges of the eroded lake sediments.
\end{abstract}

\section{Introduction}

In the present hyper-arid environment of the Western Desert of Egypt Quaternary sediments were deposited especially in playa basins in the extensive depressions during former humid periods, or shorter episodes with increased rainfall. As a result of a dissection of the sediments by gullies and wind erosion, weathering and rain-wash, the remnants of the sediments form fields of yardangs in the playas, showing various stages of evolution (Embabi, 1999, 2004). The orientation of the yardangs reflects the direction of the prevailing winds during their final erosion as well as the direction of the drainage system. In some areas, as in the Farafra depression, the distribution of the yardangs shows that they are remnants of sediments of larger lakes and not only restricted to the playa basins (Donner et al., 1999).

* Pohjoisranta 12 A 1, Helsinki 00170, Finland.

** Department of Geography, Faculty of Arts, Ain Shams University, Cairo, Egypt.

*** Department of Geography, University of Georgia, Athens GA 30602, USA. 
Even if in the playas there have been former lakes with some deposition of sediments, erosion and an effective deflation in the desert have often totally obliterated them. Stratigraphic Quaternary sequences are difficult to find, and particularly the pre-Holocene Pleistocene history of the desert is therefore poorly known and dated.

The fine-grained thinly laminated clastic sediments in the playa yardangs, in some basins with layers of chemically precipitated sediments, also contain horizons with quartz-rich aeolian sand trapped in the former lakes. On the other hand, organic layers consisting of decomposed organic matter (e.g. Embabi, 2004), the origin of which cannot easily be determined are rarely found. Because of the nature of the playa sediments the possibilities of dating them is limited. Luminescence dating, particularly OSL dating of quartz grains of aeolian sands, has, however, been especially successfully employed in dating pre-Holocene sediments, as demonstrated in the study of Bir Tarfawi and Bir Sahara in southern Egypt (Wendorf et al., 1994).

In contrast to the study of the Pleistocene history of the desert, the change from an early Holocene humid period to increasing aridity is well documented in the Sahara as a whole (Rognon, 1989; Vernet, 1995) and in the Western Desert of Egypt (Embabi, 2004). The conclusions about the humid period are mainly based on radiocarbon ages of ostrich eggshell related to artefacts, as well as ages of pieces of charcoal in fireplaces, found in playa basins. As ostrich eggshell and charcoal have not been found within the yardangs of the playa sediments, there is no direct evidence from radiocarbon dating of the sediments having been deposited during the early Holocene humid period. Luminescence dating of samples from yardangs and related sediments in Dakhla, Farafra and Bahariya has, however, given ages up to $24,000 \pm 3600$ years, thus clearly older than the Holocene (Donner et al., 2007). As most, if not all, of these sediments are pre-Holocene, it was concluded in an earlier study of the South Farafra playa (Donner et al., 1999), that there was only a shallow ephemeral lake in the basin in early Holocene time, at about 10,0007000 calibrated radiocarbon years RP. This lake was surrounded by concentrations of artefacts together with ostrich eggshell fragments, which could be used for dating (Siiriäinen, 1999). In the study of the Farafra depression, and of some sites in Dakhla and Bahariya, there was no conclusive evidence of how and when the semi-consolidated sediments in the playas, eroded into yardangs, were deposited (Donner et al., 1999, 2007), and they are therefore still of limited value in the reconstruction of the local Quaternary chronological succession. In the South Farafra playa, the sediments in the 
yardangs had a mixed assemblage of reworked-Cretaceous and Tertiary foraminifera. In addition, the diatoms in the sediments showed that they were deposited in a fresh-water lake. Hollow root casts in the basal parts of the eroded yardangs were interpreted as being remnants of a vegetation cover during the humid early Holocene period.

The dating of the early Holocene humid period has been based on the distribution of radiocarbon ages of ostrich eggshell and charcoal, not on stratigraphic evidence. In addition, the distribution of ages from U-series dating of speleothems in caves, as well as of tufas, reflect earlier humid periods, particularly the one correlated with the last interglacial, Marine Isotope Stage 5 (MIS 5), which was more humid than that of early Holocene period (Brook et al., 2003). By contrast, the use of ${ }^{230} \mathrm{Th} / \mathrm{U}$ dating of marls, carbonates and limestones in southern Egypt showed that the frequency distribution of the ages did not exactly correspond to the humid period of MIS 5 (Wendorf et al., 1994), presumably because the carbonate system in the dated samples has not remained closed with respect to $U$ and $T h$, as assumed in using the method (Steams and Thurber, 1965; Schwarcz, 1989). A comparison of the frequency distribution of published U-series ages of marine shells from Morocco, Cerastoderma ages from the Chotts in southern Tunisia and from Libya, as well as for marl, carbonate and limestone from Bir Tarfawi and Bir Sahara in southern Egypt, showed that an exact chronological frame could not be established for the humid period of MIS 5, in contrast to that based on more accurate luminescence ages (Donner, 2005). Even if the precision of the U-series ages used in dating is limited, ${ }^{230} \mathrm{Th} / \mathrm{U}$ ages were used in dating limestone beds representing lacustrine deposits in the Murzuq Basin in the desert of Libya (Gey and Thiedig, 2008). A dispersion diagram of new ages and earlier published ages showed four clusters, of which the three youngest were correlated with MIS 9, 7 and 5, whereas several ages of the clusters fell into the glacial periods MIS 10 and MIS 6. Gey and Thiedig (2008) therefore concluded that some of the ages were erroneous because the material used for dating may not have represented a closed system. The poor reliability of the ages was thus taken into account in correlating the major humid periods with the marine isotope stages.

The problems in using U-series dating were not encountered in the present study, which was based on luminescence dating, and on radiocarbon dating within its range, both methods complementing each other. After the completion of the detailed study in 1994-97 of the South Farafra playa, $10 \mathrm{~km}$ south of Qasr El-Farafra (Donner et al., 1999), the study of the Western Desert 
was continued in areas further south. A new site of promise for further investigations was eventually found, the Abu El-Egl playa, situated $140 \mathrm{~km}$

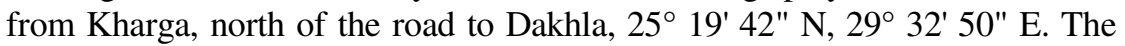
results of the study, based on field work in 2001 and 2004, were described in a joint article by Ashour et al. (2005), and later the luminescence and radiocarbon ages from the playa were discussed in a separate publication (Donner et al., 2007). Additional samples for OSL and radiocarbon dating were collected from the playa in February 2009. In the present account the emphasis is on how accurately the Quaternary development in the playa basin can be reconstructed. At the same time it is a summary of the main results from the playa, placing them in relation to results from other similar studies.

\section{The Abu El-Egl playa}

\subsection{The playa basin and its sediments}

The Abu El-Egl playa is one of the basins below the escarpment, dissected by wadis, of the Abu Tartur plateau of Palaeocene limestone between Kharga and Dakhla (Figure 1). The Late Cretaceous Santonian Taref Sandstone Formation borders the floor of the basin below the drainage channels on both its eastern and northern sides. Further up the escarpment Late Cretaceous Campanian and Maastrichtian Quseir and Duwi Formations, as well as the Palaeocene Danian Shale of the Dakhla Formation and the Landenian Limestone of the Kurkur Formation, are exposed below the plateau limestone.

The flat floor of the playa, between 169 and $175 \mathrm{~m}$ a.s.l., is covered by homogenous loamy material and partly by aeolian sand. In the middle part of the playa a number of elongated ridges or yardangs in a NNE-SSW direction, mostly with steep walls, rise 8 to $12 \mathrm{~m}$ above the basin floor up to $180 \mathrm{~m}$ a.s.l. (Figure 2). In the description of the playa by Ashour et al. (2005) it was described as a separate Pleistocene unit, the Abu El-Egl Formation. According to the description the thinly stratified sediments consist mainly of gypsiferous clay, marl, dolomitic bands, gypsum, siltstone and anhydrite, with some sandy layers. Ashour et al. (2005) presented a table of the Type Section in the playa, listing 14 layers (Figure 3 ). The results of the chemical analyses of the sediments (Table 2 in Ashour et al., 2005) reflect not only the differences between the various layers, but also a general decrease of $\mathrm{SiO}_{2}$ towards the top of the section and a corresponding increase of $\mathrm{CaO}$. 


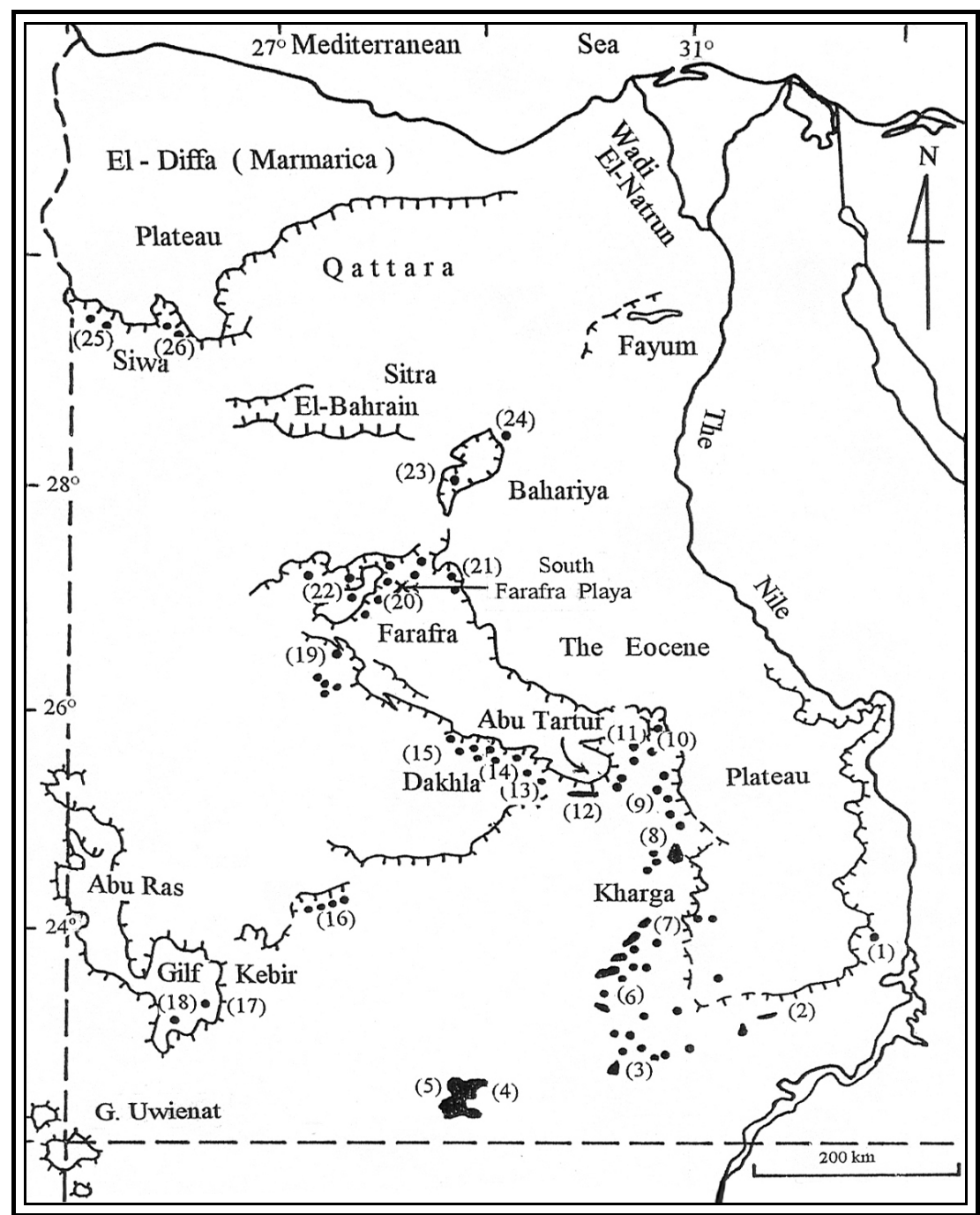

Figure 1. Distribution of Ancient Playas in The Western Desert.

(1) Kurkur (2) Dungul (3) Nabta (4) Bir Tarfawi (5) Bir Sahara (6) Bir Murr (7) G. El-Waqif (8) Paris Plain (9) Bulaq (10) EI-Maharik (11) Um El-Dabadib (12) Zayat Plain (13) Balat (14) Mut (15) West Mawhoop (16) Abu Ballas (17) Wadi Bakht (18) Wadi Ard-Al-Akhdar (19) Abu Minqar (20) Qasr El-Farafra (21) Bir Qarawin (22) Wadi El-Obied (23) El-Heiz (24) NE Bahariya (25) West Siwa (26) East Siwa.

Compiled from The Geological Map of Egypt, Scale 1: 500000, Embabi (1977) and Field Work. 


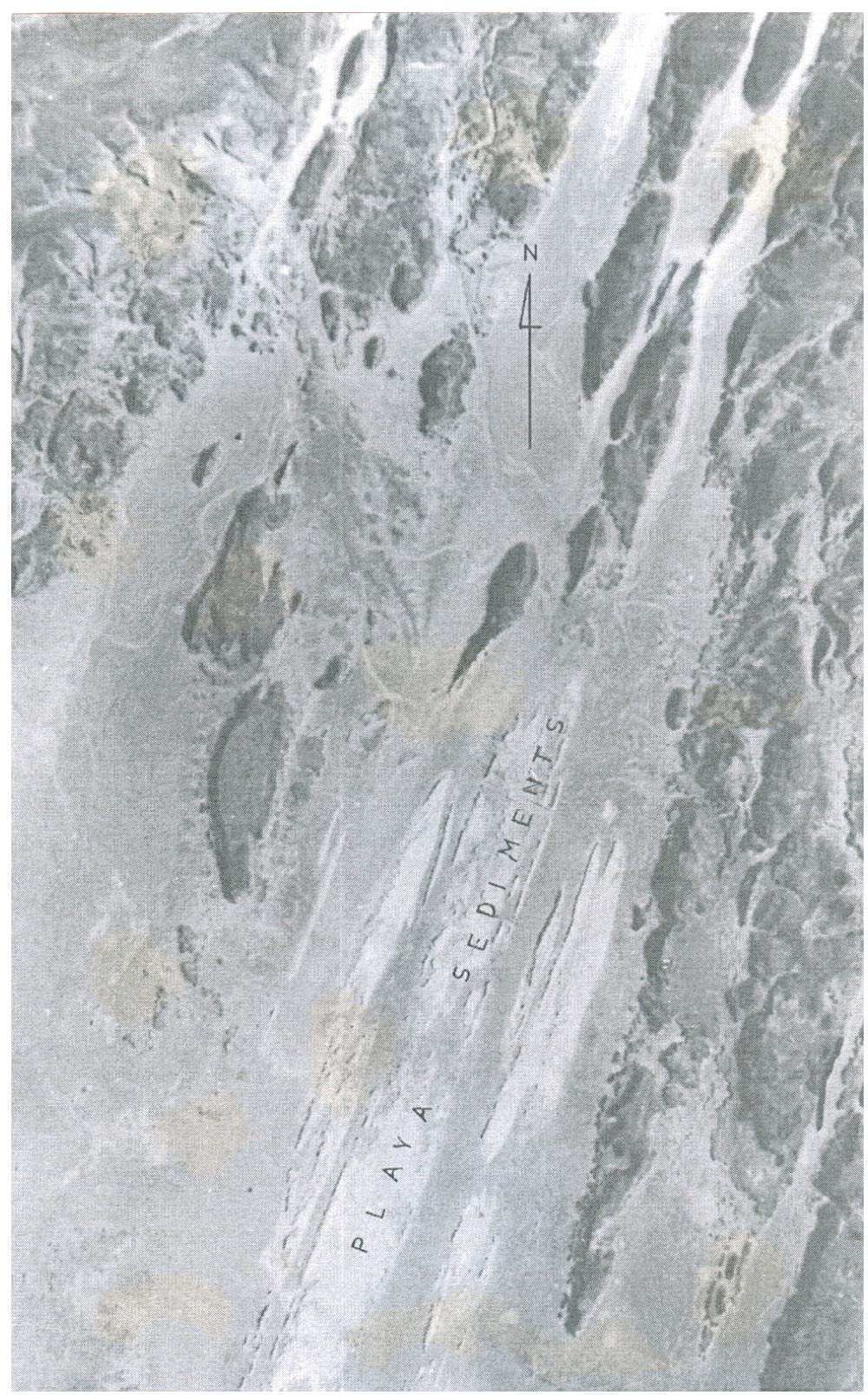

Figure 2. The elongated ridges of yardangs in NNE-SSW (whitish in colour) direction, mostly with steep walls, rise 8 to $12 \mathrm{~m}$ above the basin floor. 


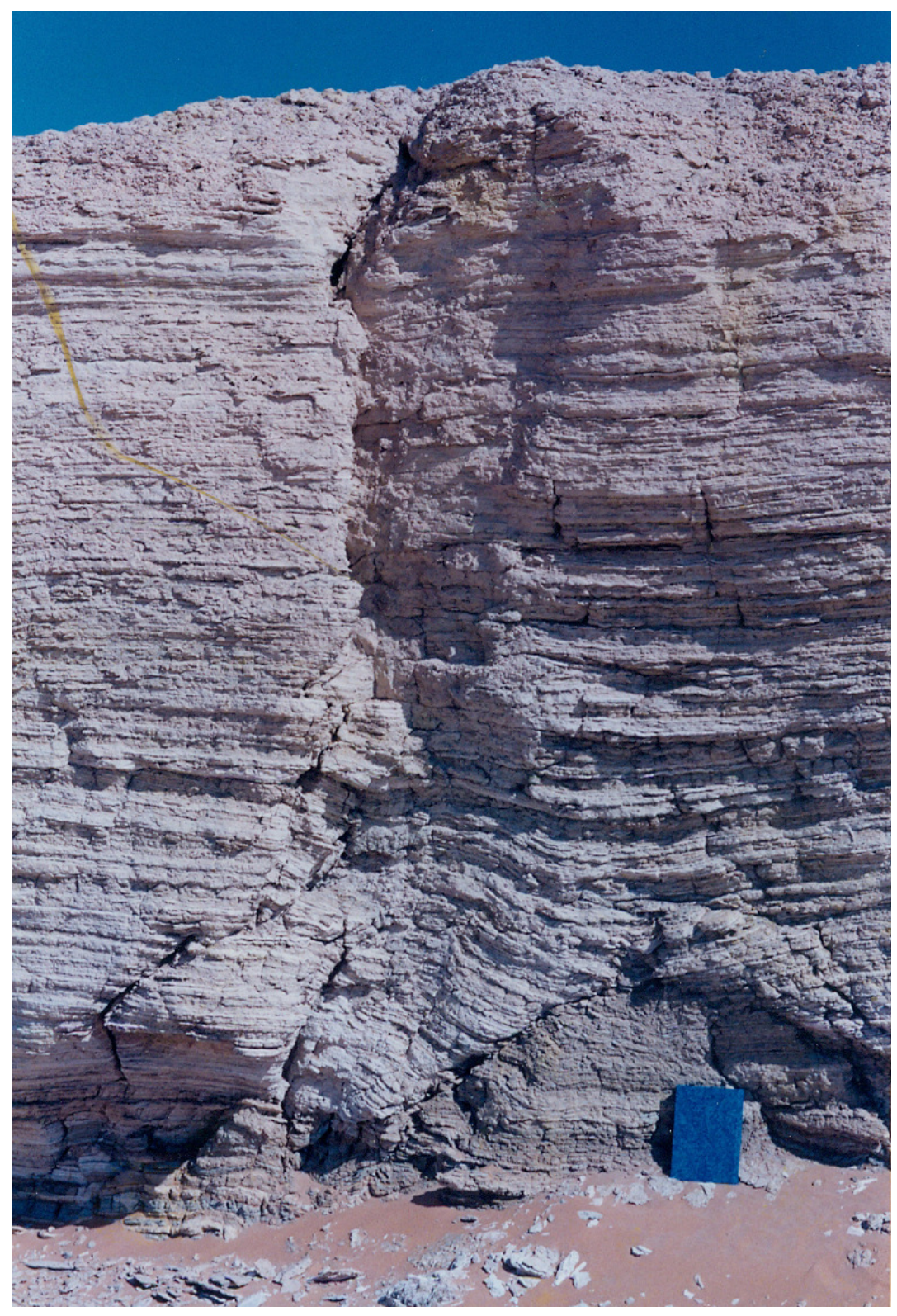

Figure 3. Abu El-Egl formation (Pleistocene) formed of successive laminas of different lithology.

\section{$-7-$}


The sediments of the Abu El-Egl Formation were interpreted as having been deposited in a shallow saline lake, with sulphur-rich ground water leading to the growth of gypsum crystals in situ during dry interruptions of the deposition of the lake sediments (Figure 4). Some thin layers of sand in the sequence consist of quartz-rich aeolian sand blown into the playa basin. There are, in addition, thin calcareous crusts with a black desert varnish of iron and manganese oxides, which cover the formerly exposed fine-grained lake sediments.

Unlike the remnants of the playa sediments of a former large lake in the Farafra depression, those in the Abu El-Egl playa were locally deposited in the playa basin, representing two sedimentary units of two successive lakes. The sediments of the Abu El-Egl Formation were deposited in the older lake with its highest level at about $180 \mathrm{~m}$ a.s.l. The lake was eventually drained and its sediments dissected. The present floor, about $10 \mathrm{~m}$ lower, represents the surface of sediments of a younger lake. Thus, on the basis of the morphology and the sediments it is possible to reconstruct the relative sequence of the deposition of the sediments in the playa.

\subsection{Luminescence dating of the playa sediments}

In the sediments of the Abu El-Egl Formation there are only a few horizons with sands containing quarz suitable for luminescence dating. It was therefore not possible to obtain a series of samples from the exposed sections (Figure 5). The luminescence dating was done at the Dating Laboratory of the University of Helsinki, with the exception of the one mentioned below. The 0.210-0.297 $\mathrm{mm}$ fraction was separated from the samples by sieving, and then density separation was used for the separation of quartz grains. They were etched by using $40 \% \mathrm{HP}$ for one hour and $10 \% \mathrm{HCl}$ for 30 minutes. The optical luminescence (OSL) measurements were made on a Ris $\varnothing$ TL-DA-12 automatic luminescence reader, using as a stimulating source blue emitting diodes (Bøtter-Jensen et al., 2000). The annual cosmic contribution was assumed to be $0.15 \mathrm{~Gy} / \mathrm{a}$.

One sample collected in 2001 (EO1/TL1) $2 \mathrm{~m}$ from the top of the Type Section at $25^{\circ} 19^{\prime} 44^{\prime \prime} \mathrm{N}, 2^{\circ} 32^{\prime} 56^{\prime \prime} \mathrm{E}$, described by Ashour et al. (2005), gave an OSL age of $79 \pm 20 \mathrm{ka}$. The annual radiation dose rate was $1.4 \mathrm{mGy}$ and the palaeodose $110.6 \mathrm{~Gy}$.

Another sample, of yellow sand collected in 2009 by George Brook near the top of a section, dated in the Luminescence Dating Laboratory of the University of Georgia, gave an OSL age of $67.6 \pm 10.7 \mathrm{ka}$. 


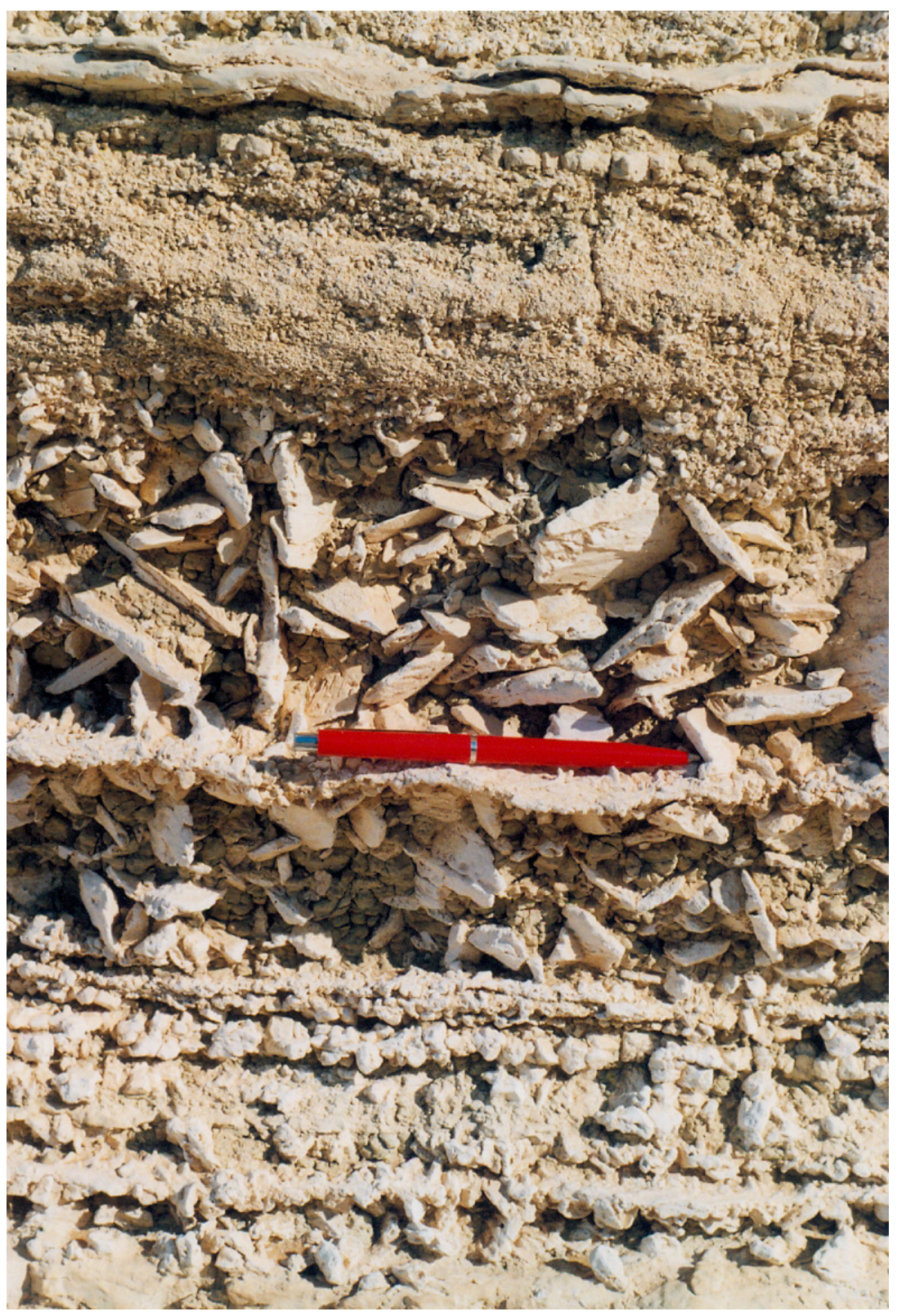

Figure 4. Gypsum crystals formed during dry interruptions of the deposition of the lake sediments.

-9- 


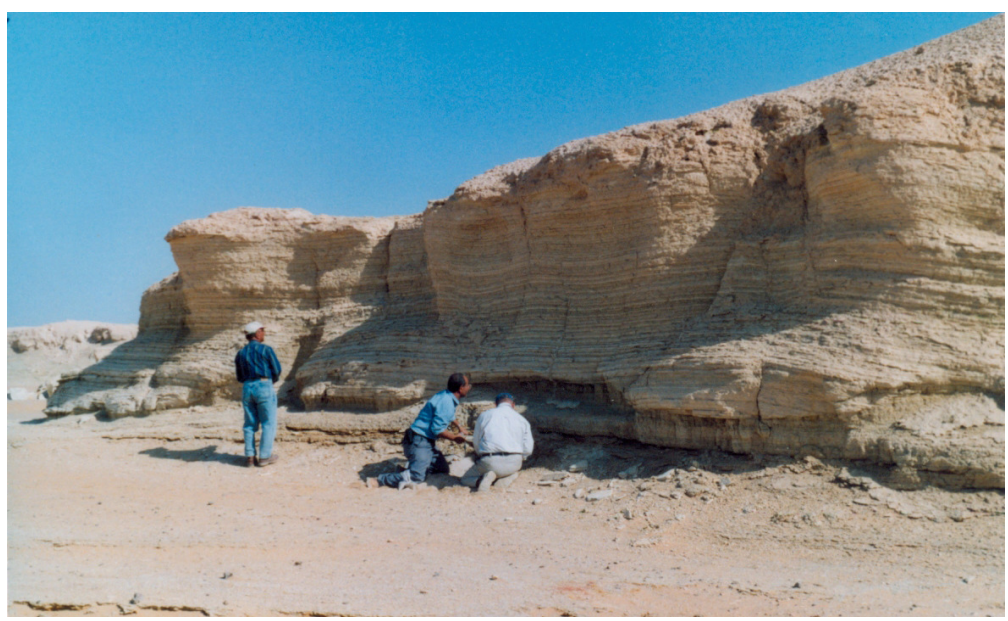

Figure 5. Collecting a sample of quartz grain from a layer of sand at the base of the Abu El-Egl formation in the southern part of playa.

In the southern part of the playa, at $25^{\circ} 18^{\prime} 55^{\prime \prime} \mathrm{N}, 29^{\circ} 32^{\prime} 17^{\prime \prime} \mathrm{E}$, a layer of sand was exposed at the base of the Abu El Egl Formation, which gave an OSL age of $110 \pm 18 \mathrm{ka}$ for a sample collected in 2004 (E TL 21 04). The annual radiation dose rate was $0.664 \mathrm{mGy}$ and the palaeodose $72.9 \pm 6.06 \mathrm{~Gy}$ (Figure 6).

E

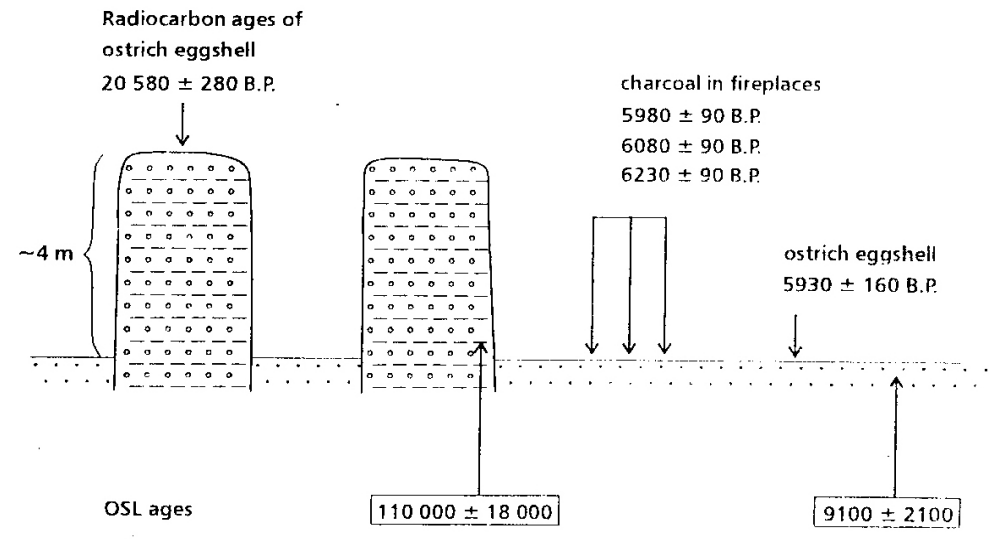

Figure 6. Schematic profile of Abu El-Egl playa with OSL and radiocarbon ages. 
In contrast to the above-mentioned pre-Holocene ages, a sample collected in 2004 (E TL1/04) from an exposure of the sandy floor in the wadi at $25^{\circ} 20^{\prime} 16^{\prime \prime} \mathrm{N} .29^{\circ} 33^{\prime} 14^{\prime \prime} \mathrm{E}$, gave a Holocene OSL age of 9.1 $\pm 2.1 \mathrm{ka}$. The annual radiation dose rate was $1.05 \mathrm{mGy}$ and the palaeodose $9.51 \pm 1.69 \mathrm{~Gy}$.

The luminescence ages listed above thus confirmed that the sediments in the playa represent two main units, the Pleistocene and Holocene formations as described by Ashour et al. (2005).

\subsection{Archaeology and radiocarbon dating}

In the publication of Ashour et al. (2005), Siiriäinen described, with photographs, the artefacts found on the Holocene floor of the Abu El-Egl playa. Probably all flakes and blades, some being side scrapers, were dated by Siiriäinen as being from the Middle Palaeolithic. In addition to the artefacts several fireplaces consisting of small mounds with a concentration of stones with a diameter between 1 and $1.5 \mathrm{~m}$, partly covered by a thin layer of drifting aeolian sand, remain at the surface of the playa floor (Figure 7). The finds of grindstones at the playa surface is further evidence of human occupation (Figure 8).

Samples of charcoal for radiocarbon dating were collected in 2001 from three fireplaces and dated at the laboratory of the University of Helsinki. The radiocarbon ages were based on the half-life of 5568 years and normalized to the $\delta{ }^{13} \mathrm{C}$ value of -25 o/oo. The CalPal- 2007 version was used for the calibration of the ages (Weninger et al., 2009). The locations of the samples and their ages and $\delta^{13} \mathrm{C}$ values were the following:

$25^{\circ} 19^{\prime} 22^{\prime \prime} \mathrm{N}, 29^{\circ} 32^{\prime} 30^{\prime \prime} \mathrm{E}$, (Hel-4560) 5980 $\pm 90 \mathrm{yr} \mathrm{BP}, 6831 \pm 110 \mathrm{cal} \mathrm{yr}$ $\mathrm{BP}, \delta^{13} \mathrm{C}-22.4$

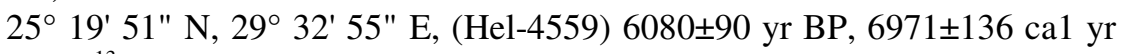
$\mathrm{BP}, \delta^{13} \mathrm{C}-22.2$

$25^{\circ} 19^{\prime} 43^{\prime \prime} \mathrm{N}, 29^{\circ} 32^{\prime} 56^{\prime \prime} \mathrm{E}$, (Hel-4557) 6230 $\pm 90 \mathrm{yr} \mathrm{BP}, 7130 \pm 112 \mathrm{cal} \mathrm{yr}$ $\mathrm{BP}, \delta^{13} \mathrm{C}-24.8$

Fragment of ostrich eggshell were also found in the Abu El-Egl playa associated with artefacts, as in Holocene playas. One sample of eggshell, found together with a flake described and illustrated by Siiriäinen (Ashour et al., 2005, Sample E 01/3), near a $53 \mathrm{~cm}$ long grindstone, gave the following age:

$25^{\circ} 18^{\prime} 39^{\prime \prime} \mathrm{N}, 29^{\circ} 32^{\prime} 25^{\prime \prime} \mathrm{E}$, (Hel-4556) 5930 $\pm 160 \mathrm{yr} \mathrm{BP}, 6779 \pm 200 \mathrm{ca}$ yr $\mathrm{BP}, \delta^{13} \mathrm{C}+1.4$ 


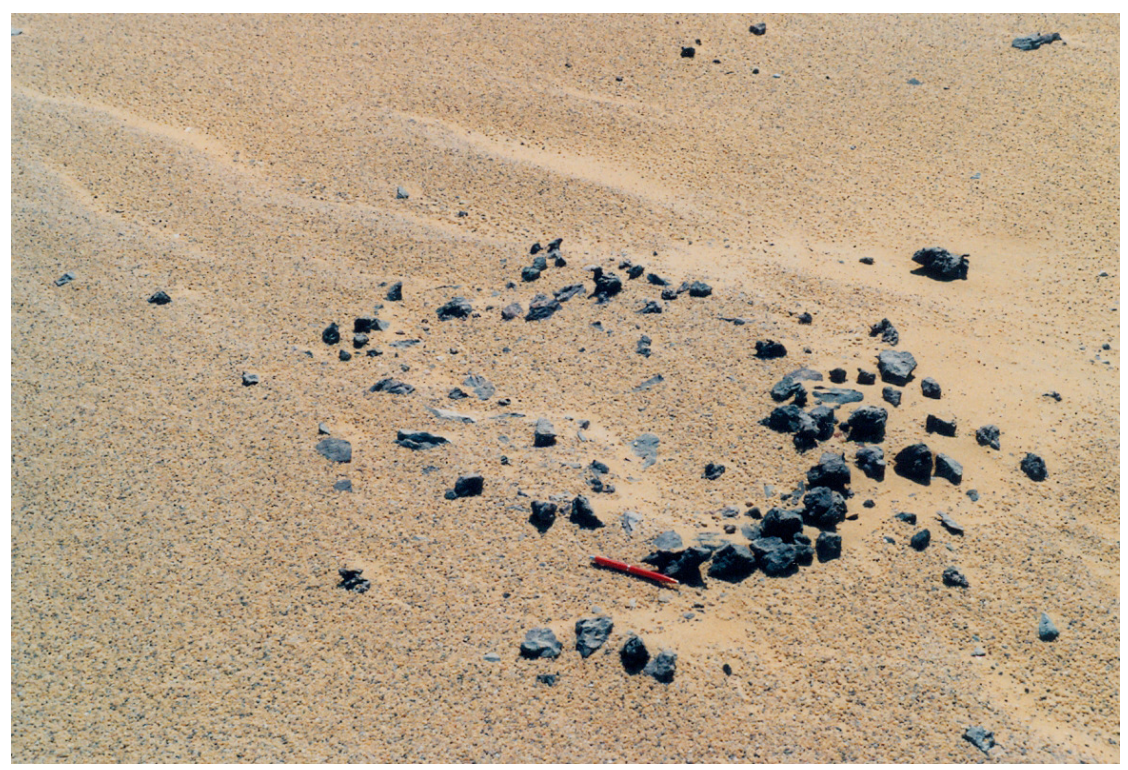

Figure 7. Fireplace with a diameter of $1.5 \mathrm{~m}$, consisting of small mound with concentration of stones, remain at the surface of the playa floor.

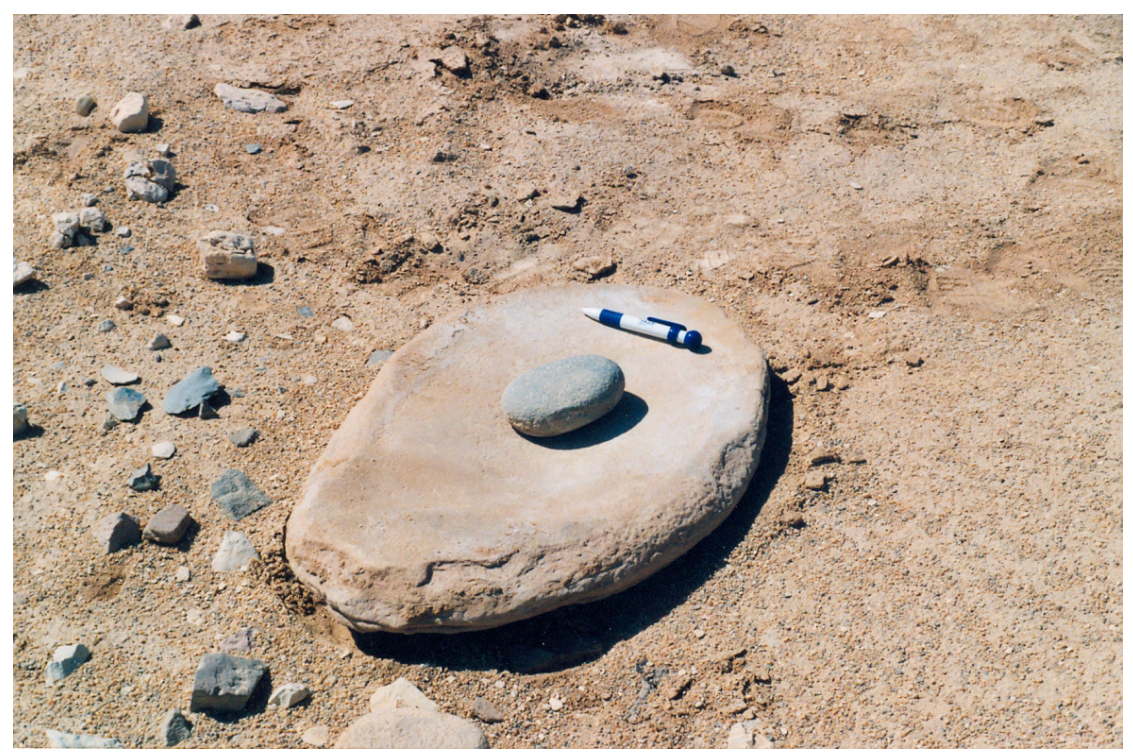

Figure 8. A grinding stone mad of granite found on the basin floor.

$-12-$ 
The above-mentioned radiocarbon ages related to the archaeological finds show that there was some vegetation and enough water for the playa floor to have been occupied in the early Holocene. But as there could not have been a lake in the playa the supply of water was limited to a discharge of ground water and some drainage from higher ground. A small hollow cut into the older Pleistocene sediments was interpreted as forming a dam to collect rainwater (Ashour et al., 2005). During the human occupation of the playa fresh water must have been available in the basin, which had formerly been a saline lake.

In addition to the charcoal in the fireplaces and the ostrich eggshell fragments on the Holocene floor of the playa, large pieces of ostrich eggshell were found in a shallow hollow with aeolian sand on top of the uneven surface of the dissected Pleistocene sediments, at the upper level of the old lake. The radiocarbon dating gave the following age:

$25^{\circ} 19^{\prime} 32 \mathrm{~N}, 29^{\circ} 32^{\prime} 59^{\prime \prime} \mathrm{E}$, (Hel-4561) 20,580 $\pm 280 \mathrm{yr} \mathrm{BP}, 24,510 \pm 411 \mathrm{cal} \mathrm{yr}$ $\mathrm{BP}, \delta^{13} \mathrm{C}+0.1$

The age of the eggshell shows that the deposition of lake sediments into the Pleistocene lake had ceased about 24,000 years ago, well before the Holocene.

A sample collected in 2009 from a clayey horizon in the Pleistocene sediments contained enough organic matter for AMS dating, which was done at the University of Georgia. The age was the following:

$23,750 \pm 70$ yr BP, $28,656 \pm 390$ yr cal yr BP, $\delta{ }^{13} \mathrm{C}-20.6$

The age is older than that for the ostrich eggshell sample from the surface of the sediments, but clearly younger than the three luminescence ages for the sands in them.

\section{Conclusions and Discussion}

On the basis of the stratigraphy of the Abu El-Egl playa sediments, and the luminescence and radiocarbon ages, the Pleistocene and Holocene history of the basin can be reconstructed (Figure 6). The thinly stratified sediments of the Abu El-Egl Formation, as described by Ashour et al. (2005), were deposited in a shallow saline lake up to the level of $180 \mathrm{~m}$ a.s.l., about $12 \mathrm{~m}$ above the present playa floor. Of the three OSL ages, $110 \pm 18 \mathrm{ka}, 79 \pm 20 \mathrm{ka}$ and $67 \pm 10.7 \mathrm{ka}$, of sands in the lake deposits, the two 
older ages fall within the range of MIS 5 (Martinson et al., 1987; Tzedakis et al., 2001). The third age is younger than the MIS 5/4 boundary at about 74 $\mathrm{ka}$, but considering the margin of error of $10.7 \mathrm{ka}$ it can still be within the range of MIS 5; the marine isotope stages are used in the present account only as a general chronological frame on which to base the discussion.

The lake into which the sediments of the Abu El-Egl Formation were deposited was eventually drained, which led to the dissection of the sediments into elongated ridges remaining about $10 \mathrm{~m}$ above the floor with Holocene sediments. As the erosion of the sediments was by necessity a combination of the effect of both running water and wind abrasion, at least in the beginning, it took place after MIS 5 at times with a relatively humid climate. The age of the ostrich eggshell fragments on top of the sediments indicates that the deposition of the old lake sediments had ceased before about 24,500 years BP. The organic matter in the sediments, with a radiocarbon AMS age of over 28,000 years BP is at variance with the three much older OSL ages with a wide range broadly within that of MIS 5. The AMS age can at best date the remains of some plants, possibly algae, which grew in the sediments during a subsequent humid episode.

As the deposition of the Pleistocene sediments of the Abu El-Egl Formation took place during a period broadly corresponding to MIS 5, the erosion could have started at any time after that. The scattered finds of Middle Palaeolithic artefacts on the exposed Holocene floor at about $170 \mathrm{~m}$ a.s.l., and not at $180 \mathrm{~m}$ a.s.l., show that the Pleistocene sediments were eroded at latest during MIS 3, the relatively long humid period lasting about $35 \mathrm{ka}$, from about $60 \mathrm{ka}$ to about $25 \mathrm{ka}$, thus a period agreeing with the above-mentioned AMS age of organic matter in the sediments. According to Wendorf et al. (1994) the Middle Palaeolithic is associated with MIS 3 in the desert of southern Egypt, with the former lakes in Bir Tarfawi and Bir Sahara. A humid period during MIS 3 has also been identified in Western Sahara, associated with Aterian artefacts (Petit-Maire, 1991), but because of uncertainties in the dating methods used, particularly that of ${ }^{230} \mathrm{Th} / \mathrm{U}$ dating, some of the conclusions have been questioned, as discussed by Rognon (1989) and Vernet (1995). Clear evidence of MIS 3 having been a long humid period in the Sahara is, however, shown by the over 300 radiocarbon groundwater ages from the Sahara (Sonntag et al., 1980). The frequency distribution of the ages from Egypt shows higher frequencies for the long period of MIS 3, and again for the Holocene, with few ages from the arid period of MIS 2. 
The age of $24,510 \pm 411 \mathrm{cal}$ yr BP for ostrich eggshell from the surface of the Pleistocene sediments shows that at the end of MIS 3 the climate was still humid, with enough water and a vegetation cover that could sustain ostriches and humans in the area. Then followed the arid period of MIS 2 in the Sahara, with no evidence of human settlement in the Abu El-Egl playa, and no sediments dated as having been deposited during this period. During the arid period the strong winds from the north presumably further eroded the fine-grained sediments of the old lake, with deflation of the earlier eroded playa floor.

The increased humidity in the beginning of the Holocene led to the deposition of the homogenous loamy material in the playa basin and north of the dissected ridges of sands by streams, as seen by the network of small channels in the wadi. The top of these sands gave the OSL age of 9.1 2.1 ka. The playa floor could be occupied after the initial early Holocene deposition of sediments in a shallow short-lived lake at about $170 \mathrm{~m}$ a.s.l., as shown by the fireplaces and grindstones at the surface. Three radiocarbon ages of charcoal, and the one of ostrich eggshell, all gave an age around $7000 \mathrm{yr}$ BP for this Neolithic occupation. The lack of artefacts associated with the fireplaces indicates that there was not necessarily a permanent occupation in the playa, but that the fireplaces were those of camping nomadic people, as suggested by Gabriel (1987) in a general discussion on their distribution in the Sahara. The playa was eventually abandoned as a result of increasing aridity later in the Holocene, in an area without any vegetation and where the mean annual rainfall at present is less than one $\mathrm{mm}$.

The deposition and erosion of the Quaternary sediments in the Abu ElEgl playa, and the later human occupation, were, as concluded, governed by the alternating humid and arid periods in the Western Desert of Egypt. The deposition of the Abu El-Egl Formation, as defined by Ashour et al. (2005), took place during MIS 5, a period where humid episodes corresponding to MIS 5e, c and a alternated with arid episodes of MIS 5d and b in Eastern Sahara (Szabo et al., 1995). Thus, the interruptions in the deposition of the sediments in the Abu El-Egl playa, with horizons of gypsum crystals, reflect changes in humidity within MIS 5, even if a detailed correlation of these changes with MIS 5 cannot be established.

The Quaternary history of the Abu El-Egl playa, as reconstructed in the present study, covers the period from MIS 5 to the present, with two lake 
stages, at 180 and $170 \mathrm{~m}$ a.s.l., separated by a period of erosion after the drainage of the older lake. As the playa basin is situated below the escarpment of the Abu Tartur plateau, on the lee-side of the prevailing winds from the north, remnants of the old lake sediments still remain as dissected ridges in the playa. The reconstruction of the history of the playa was made possible by using both OSL ages of the sediments and radiocarbon ages of ostrich eggshell and charcoal. In earlier studies a similar chronological control has been lacking when sediments like those in the Abu El-Egl playa were studied, as pointed out by Brookes (1993) in his detailed investigation in the Dakhla Oasis region. The demonstrations of former pluvial episodes, correlated with interglacials, have in some studies been based on tufas and travertines combined with stable isotope analyses. Spring tufas occur at many localities in Kharga, and in some areas, as in Wadi Mildauwara south-east of Kharga at the edge of the Libyan Plateau, several units have been identified, one correlated with MIS 5 on the basis of uranium-series dating (Smith et al., 2004; Kieniewicz and Smith, 2007). Further south, in Kurkur Oasis, the plateau and spring travertines were formed during pluvials with a great range of uranium-series ages (Crombie et al., 1997). In spite of the uncertainties in uranium-series dating, the ages of tufas and travertines support the conclusions about the timing of the humid periods in the Western Desert, especially the one correlated with MIS 5 documented at several localities.

\section{Acknowledgements}

The authors are grateful to Kamal A. Abu Zeid, of the Geological Survey of Egypt, who took part in the original study in 2001 of the geological surrounding and the sediments of the Abu El-Egl playa.

\section{References}

1. Ashour, M.M., Embabi, N.S., Donner, J. \& Abu Zeid, K.A. 2005. Geomorphology and Quaternary geology of Abu El-Egl a playa, Western Desert of Egypt. Bulletin of the Egyptian Geographical Society 78, 1-26.

2. Bøtter-Jensen, L., Bulur, E., Duller, G.AT. \& Murray, A.S. 2000. Advances in luminescence systems. Radiation Measurements 32, 523-528.

3. Brook, G.A, Embabi, N.S., Ashour, M.M., Edwards, R.L., Cheng, H., Cowart, J.R. \& Dabous, AA. 2003. Quaternary environmental change in the Western Desert of Egypt: Evidence from cave speleothems, spring tufas, and playa sediments. Zeitschrift für Geomorphologie, N.F. 131, 59-87.

4. Brookes, I.A. 1993. Geomorphology and Quaternary geology of the Dakhla Oasis region, Egypt. Quaternary Science Review 12, 529-552. 
5. Crombie, M.K., Arvidson, R.E., Sturchio, N.C., El Alfy, Z. \& Abu Zeid, K. 1997. Age and isotopic constraints on Pleisocene pluvial episodes in the Western Desert, Egypt. Palaeogeography, Palaeoclimatology, Palaeoecology 130, 337-355.

6. Donner, J.J., Ashour, M.M., Embabi, N.S. \& Siiriäinen, A. 1999. The Quaternary geology of a playa in Farafra, Western Desert of Egypt. Annales Academiae Scientiarum Fennecae, Geologica-Geographica 160, 49-112.

7. Donner, J. 2005. On the dating of Pleistocene humid periods in the Sahara. Bulletin of the Egyptian Geographical Society 78, 81-90.

8. Donner, J, Ashour, M.M., Embabi, N.S. \& Jungner, H. 2007. Luminescence dating of Quaternary sediments: Samples from the Western Desert of Egypt. Bulletin of the Egyptian Geographical Society 80, 115-126.

9. Embabi, N.S. 1999. Playas in the Western Desert, Egypt. Annales Academiae Scientiarum Fennicae, Geologica-Geographica 160, 5-47.

10. Embabi, N.S. 2004. The Geomorphology of Egypt, Landforms and Evolution, Volume I, The Nile Valley and the Western Desert. The Egyptian Geographical Society, $447 \mathrm{pp}$.

11. Gabriel, B. 1987. Palaeontological evidence from Neolithic fireplaces in the Sahara. The African Archaeological Review 5,93-103.

12. Gey, M.A. \& Thiedig, F. 2008. The Middle Pleistocene Al Mahruqah Formation in the Murzuq Basin, northern Sahara, Libya evidence for orbitallyforced humid episodes during the last 500,000 years. Palaeogeography, Palaeoclimatology, Palaeoecology 257, 1-21.

13. Kieniewicz, J.M. \& Smith, J.R. 2007. Hydrologic and climatic implications of stable isotope and minor element analyses of authigenic calcite silts and gastropod shells from a midPleistocene pluvial lake, Western Desert, Egypt. Quaternary Research 68: 431-444.

14. Martinson, D.G., Pisias, N.G., Hays, J.D., Imbrie, J., Moore, Jr., T.C. \& Shackleton, M.J 1987. Age dating and the orbital theory of the Ice Ages: Development of a high-resolution 0 to 300,000-year chronostratigraphy. Quaternary Research 27, 1-29.

15. Petit-Maire, N. 1991. Recent Quaternary climatic change and Man in the Sahara. Journal of African Earth Sciences 12(112): 125-132.

16. Rognon, P. 1989. Biographie d'un desert. Le Sahara. L'Harmattan, Paris (1994), 347 pp.

17. Schwarcz, H.P. 1989. Uranium series dating of Quaternary deposits. Quaternary International 1, 7-17.

18. Siiriäinen, A. 1999. Archaeological evidence for dating the sediments in a playa in Farafra, Western Desert of Egypt. Annales Academiae Scientiarum Fennicae, Geologica-Geographica 160, 113-146.

19. Smith, JR., Giegengack, R. \& Schwarcz, H.P. 2004. Constraints of Pleistocene pluvial climates through stable-isotope analysis of fossil-spring tufas and associated gastropods, Kharga Oasis, Egypt. Palaeogeography, Palaeoclimatology, Palaeoecology 206, 157-175. 
20. Sonntag, C., Thorweihe, U., Rudolph, J., Löhnert, E.P., Junghans, C., Münnich, K.O., Klitzsch, El-Shalzly, E.M. \& Swailem, F.M. 1980. Paleoclimatic evidence in apparent ${ }^{14} \mathrm{C}$ ages on Saharian groundwaters. Radiocarbon 22(3), 871-878.

21. Stearns, C.E. \& Thurber, D.L. 1965. Th 230 - U 234 dates of late Pleistocene marine fossils from the Mediterranean and Moroccan littorals. Quaternaria 7, 29-42.

22. Szabo, BJ., Haynes Jr., C.V. \& Maxwell, T.A. 1995. Ages of Quaternary pluvial episodes determined by uranium-series and radiocarbon dating of lacustrine deposits in Eastern Sahara. Palaeogeography, Palaeoclimatology, Palaeoecology 113, 227-242.

23. Tzedakis, P.C., Andrieu, V., de Beaulieu, J-L., Birks, H.J.B., Crowhurst, S., Follieri, M., Hooghiemstra, H., Magri, D., Reille, M., Sadori, L., Shackleton, N.J. \& Wijmstra, T.A. 2001. Establishing a terrestrial chronological framework as a basis for biostratigraphical comparisons. Quaternary Science Reviews 20, 1583-1592.

24. Vernet, R. 1995. Climats anciens du nord de l'Afrique. L'Harmattan, Paris, 180 pp.

25. Wendorf, F., Schild, R., Close, A.E., Schwarcz, H.P., Miller, G.F., Grün, R., Bluszcz, A., Stokes, S., Morawska, L., Huxtable, J., Lundberg, J., Hill, C.L. \& McKinney, C. 1994. A chronology for the Middle and Late Pleistocene wet episodes in the Eastern Sahara. In: Bar-Yosef, O. and Kra, R. (editors) Late Quaternary chronology and paleoclimates on the Eastern Mediterranean. Tuscon, Arizona: Radiocarbon, 147-168.

26. Weninger, B., Jöris, O. \& Danzeglocke, U. 2009. CalPal - 2007. Cologne Radiocarbon Calibration and Palaeoclimate Research Package. http://www.calpac.de/, accessed 2009-5-6.

* * * *

